\title{
Antifungal Immunological Defenses in Newborns
}

\author{
Christina Michalski ${ }^{1,2}$, Bernard Kan ${ }^{1,2}$ and Pascal M. Lavoie ${ }^{1,2,3 *}$ \\ ${ }^{1}$ British Columbia Children's Hospital Research Institute, Vancouver, BC, Canada, ${ }^{2}$ Department of Medicine, University of \\ British Columbia, Vancouver, BC, Canada, ${ }^{3}$ Department of Pediatrics, University of British Columbia, Vancouver, BC, \\ Canada
}

Newborns are prone to fungal infections, largely due to Candida species. The immunological basis for this vulnerability is not yet fully understood. However, useful insights can be gained from the knowledge of the maturation of immune pathways during ontogeny, particularly when placed in context with how rare genetic mutations in humans predispose to fungal diseases. In this article, we review these most current data on immune functions in human newborns, highlighting pathways most relevant to the response to Candida. While discussing these data, we propose a framework of why deficiencies in these pathways make newborns particularly vulnerable to this opportunistic pathogen.

\section{OPEN ACCESS}

Edited by:

Joseph M. Bliss,

Women \& Infants Hospital of

Rhode Island, USA

Reviewed by:

Dolores Correa,

Instituto Nacional de

Pediatria, Mexico

Adilia Warris,

University of Aberdeen, UK

*Correspondence:

Pascal M. Lavoie

plavoie@cw.bc.ca

Specialty section:

This article was submitted to

Microbial Immunology,

a section of the journal

Frontiers in Immunology

Received: 05 January 2017

Accepted: 28 February 2017

Published: 15 March 2017

Citation:

Michalski C, Kan B and Lavoie PM

(2017) Antifungal Immunological

Defenses in Newborns.

Front. Immunol. 8:281.

doi: 10.3389/fimmu.2017.00281
Keywords: neonate, immunology, fungus, Candida, humans, infection, prematurity

\section{INTRODUCTION}

Fungi are present everywhere in the environment, including in water, on solid surfaces, on our skin, and gastrointestinal tract. Taxonomists estimate the existence of 1.5 to over 5 million fungal species, although only a small minority ( $<300$ species) causes diseases in humans (1). Despite their ubiquitous presence, fungi rarely become invasive in healthy adults due to multiple levels of immune defenses. In contrast, fungal infections are common in newborns and can be particularly invasive in those born very prematurely $(2,3)$.

A number of studies have investigated the functional characteristics of newborn immune cells [reviewed in Ref. $(4,5)]$. The immune system is composed of two main arms involved in the recognition of fungi. Developmental changes in some of the main immune pathways involved in responses against Candida are illustrated in Figure 1. During gestation, innate immune cells are skewed toward anti-inflammatory responses. Adaptive immune cells also lack immunological memory from prior exposure to antigens and are skewed toward a T helper 2 (Th2) effector profile. These changes are essential to prevent allogeneic maternal rejection and during the establishment of tolerance toward self-antigens. Moreover, the expansion and maturation of immune cells is incomplete in infants born very prematurely, which further increases their vulnerability to infections $(4,5)$. These functional limitations are also affected by pregnancy complications, which can be linked to a premature birth $(6,7)$.

While our knowledge of the maturation of immune pathways in human newborns has greatly progressed recently, few of these studies have focused on fungi as model organisms. Therefore, our understanding of the immunological basis for the increased susceptibility of the neonatal immune system to fungi remains limited. Nonetheless, insights can be gained from rare genetic mutations predisposing to localized or invasive Candida infections in humans. These data have been recently covered by other experts $(8,9)$. The clinical presentation, risk factors, and treatment of neonatal Candida infections have also been reviewed recently $(10,11)$. This review discusses recent data 


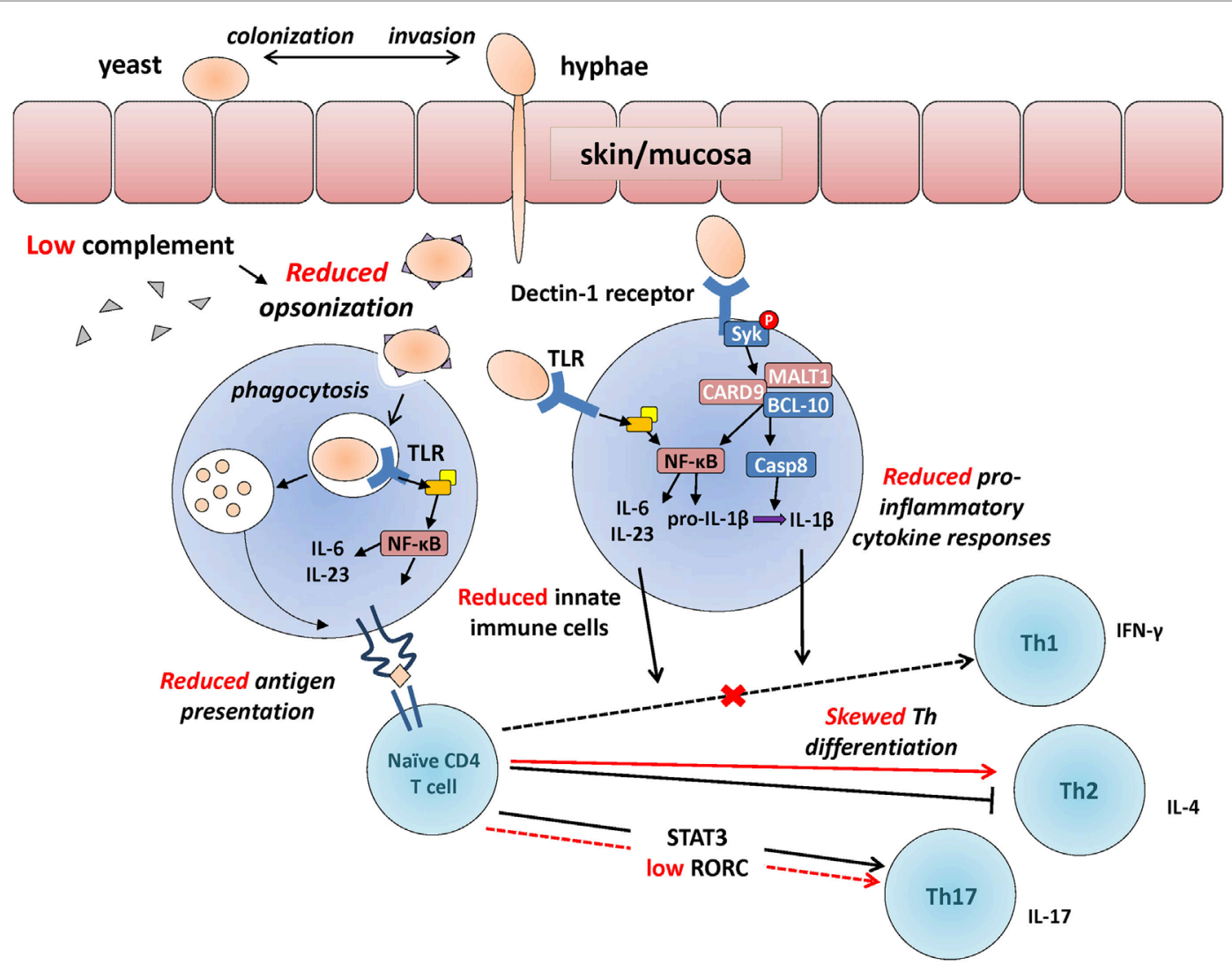

FIGURE 1 | Developmental changes in the immunological response to Candida. Developmental differences in some of the main immunological events involved in the recognition of Candida, between adults (in black) and neonates (in red, cross also indicates a reduction in neonates compared to adults). Candida colonizes the skin or mucosa as yeast but often invades in hyphae form allowing to penetrate through epithelial barriers more efficiently. Upon innate immune detection of Candida through pattern recognition receptors [e.g., toll-like receptors (TLRs); Dectin-1 receptor], microorganisms get opsonized (reduced in preterm neonates), facilitating phagocytosis and resulting in the production of pro-inflammatory cytokines (also reduced in neonates) through Syk and NFkB-mediated intracellular signaling. Internalized Candida antigens are presented (reduced in neonates) to naïve CD4 T cells, resulting in their differentiation into Th1/Th17 effector cells (skewed toward T helper 2 in neonates). Whereas deficiencies in innate functions (e.g., MALT-1/CARD9) can lead to invasive candidemia, selective deficiencies in adaptive functions (e.g., IL-17 responses) most often lead to chronic mucocutaneous infections.

underlying the immunological basis for newborns' increased susceptibility to Candida infections.

\section{NEONATAL CANDIDA INFECTIONS}

In newborns, Candida is responsible for the common oral thrush and rash in skin folds and in the diaper area. Before the advent of modern sanitary measures and topical antifungal treatments, infants died from dehydration due to severe oral mucocandidiasis (12). Nowadays, invasive infections are rare with the exception of infants born very premature, those who require prolonged indwelling medical devices, or in cases of a primary immunodeficiency $(8,13)$.

Once invasion occurs, the mortality from Candida infections in newborns is high, and so is the associated morbidity: up to twothirds of those who survive will suffer long-term impairments (14). Similarly, fungemia due to other genera such as Malassezia (15), Aspergillosis (16), and Zygomycosis (17) also carry a high mortality, though these infections are more rare. Dermatophytes infrequently cause skin infections in young infants.
At birth, neonates generally have a low fungal burden (18-20); however, colonization occurs in a majority of neonates through both vertical (mother-to-child) and horizontal (nosocomial) transmission (20-28). Most invasive Candida infections occur between the second and sixth week postnatal age $(29,30)$ owing to the timing of colonization. Candida albicans is the most frequently isolated Candida species, but other species, particularly Candida parapsilosis, but also Candida tropicalis, Candida glaberata, and Candida kruzei are becoming more prevalent (11, 31-33). Interestingly, major variations have been reported in the incidence and species distribution of Candida infection among neonatal intensive care units across the world $(3,34,35)$. For example, in North America and Europe, invasive disease almost exclusively occurs in infants of birth weight less than $1,000 \mathrm{~g} \mathrm{(2,}$ $11,36,37$ ), whereas up to $15 \%$ of infants born below 33 weeks in neonatal center in Shanghai were diagnosed with a systemic fungal infection (38). These variations may be due to racial differences in immune phenotypes, although this has not been formally examined in the context of Candida infections. On the 
other hand, these differences in epidemiology are more likely due to geographical variations in infection control measures and in the use of broad spectrum antibiotics.

\section{INNATE IMMUNE RESPONSES}

The innate immune system is the first-line of immune defenses responsible for signaling the presence of microorganisms and riding our body from an invasion through opsonization (i.e., targeted labeling), cell-to-organism killing, and phagocytosis. The epithelial layers (skin and mucosa) are the first line of defense of the innate immune system against a fungal invasion $(39,40)$. Highly premature infants lack vernix caseosa, which is a natural substance composed of antimicrobial sebum, covering the skin of term newborns $(41,42)$. This lack of vernix caseosa may increase fungal invasion by affecting the balance between the infant's bacterial and fungal flora (42). However, this contention, at this point, remains speculative and requires further study.

\section{Antimicrobial Peptides}

Antimicrobial peptides are a major component of innate immune defenses. These peptides generally show reduced levels in those born prematurely [reviewed in Ref. (43)]. Levels of $\alpha$-defensin have been correlated with the presence of mannan in bronchoalveolar lavage fluids from preterm neonates, indicating a role in controlling fungal growth at mucosal surfaces (44). Complement proteins are another major component, consisting of at least 20 interdependent components that are deposited on the surface of pathogens, resulting in phagocytosis via opsonization, killing via pore-formation, and activation of inflammatory cytokine responses. In mice, deficiencies in complement proteins, particularly C3, result in an inability to clear infections due to C. albicans and Candida glabrata (45). Human C5a also appears important for induction of inflammatory cytokine responses to C. albicans (46). In one case, a child with a hereditary C3 deficiency was unable to opsonize this microorganism and normal function was restored with C3 supplementation (47); deficiencies in factor $\mathrm{H}$ and factor I have also been shown to negatively affect killing of C. albicans (48). Production of complement proteins is detectable early on in the fetus during ontogeny (49) and increases in a gestational age-dependent manner until the term of gestation and even after birth $(50,51)$. Therefore, it is possible that relative complement deficiencies in newborns may increase susceptibility to invasive Candida infections, but to a relatively minor extent.

\section{Phagocytes}

Innate immune cells such as neutrophils, macrophages/monocytes, and dendritic cells play important roles in preventing a fungal invasion [reviewed in Ref. (52)]. In mice, depletion of neutrophils increased susceptibility to cutaneous Candida infections (53) and also increased the risk of lethal invasion following experimental mucosal damage (54). Humans with genetic defects that impair neutrophil functions, such as the autosomal recessive myeloperoxidase deficiency, are at greatly increased risk of systemic Candidiasis, suggesting an important role for neutrophils and other phagocytes (55). Neutrophil extracellular traps (NETs) facilitate killing of C. albicans, although their functional importance against this pathogen is debated (55-57). NET formation upon Candida exposure is operational in newborns and, therefore, a neonatal deficiency in NET does not explain their susceptibility to infections (58). On the other hand, neutropenia due to a central, bone marrow cause, severely predisposes to systemic candidiasis in adults (59). In the fetus, bone marrow production of hematopoietic cells rapidly increases after the 20th week of gestation $(4,5)$. Consequently, lower neutrophil and monocyte cell counts are observed in extremely low gestation preterm infants, which may play a more important role in increasing the risk of systemic infections in these infants $(60,61)$. Interestingly, neutropenia is often not observed during Candida sepsis in preterm neonates, in contrast to Gram-negative bacteria, which may indicate a more limited role for these cells once invasive infection has occurred (62).

In addition to a relatively limited neutrophil cell count, some studies have reported reduced neutrophil function in very preterm neonates. In a whole blood assay, reduced migration and phagocytosis of C. guillermondii was observed in very low birth weight $(<1,500 \mathrm{~g})$ infants compared to term neonates and adults (63). However, a recent study reported no difference in phagocytosis and oxidative burst between age groups (64). In general, phagocytosis functions are relatively preserved in very preterm neonates (65-67). These differences in findings may be due to differences in the assay or strain of Candida that have been used between these studies. More functional in vitro studies are required using Candida in order to help resolve these findings.

Monocytes/macrophages also appear to play an important role in preventing a Candida invasion based on mouse studies (52). Monocytes rely primarily on non-opsonic phagocytosis via Dectin-1 and Dectin-2 (68). To the best of our knowledge, the response of macrophages (or monocytes) to Candida has not been studied in infants born prematurely.

\section{Pathogen Recognition}

The lipid bilayer of Candida is surrounded by chitin, an inner cell wall component made of polysaccharides ( $\beta, 1-3$ glucan, $\beta, 1-6$ glucan) and an outer cell wall composed of $\mathrm{N}$-linked glycoproteins coated with mannan polymers (69). C. albicans can transform between yeasts and hyphae based on the environmental conditions (70). These two forms have different virulence and elicit different immune responses due to structural changes in their cell wall $(70,71)$. Immune cells recognize the presence of pathogens through innate receptors called pattern recognition receptors (PRRs). PRR can be free circulating in body fluids (e.g., pentraxin, collectins, or ficollins) or cell associated. Cell-associated PRRs include toll-like receptor (TLR), C-type lectin receptors (CLRs), and the intracellular (cytoplasmic) NOD-like receptors (NLRs) and RIG-I-like receptors (RIRs). Several PRR are involved in the immune recognition of Candida, including TLR2, TLR4, TLR6, and CLRs and in the recognition of Candida DNA (e.g., TLR3 and TLR9) (72-74). Recognition of fungi by multiple PRRs triggers a cascade of immune activation events including the production of cytokines, reactive oxygen species, and the activation of phagocytosis. These multiple levels of immune recognition enhance immune protection in healthy individuals. 
In newborns, PRR functionality develops early in the third trimester of gestation, beginning with endosomal/cytoplasmic PRR around 20-24 weeks, followed by extracellular PRR until about 33 weeks of gestation when the PRR functionality compares to that of full-term infants $(7,75,76)$ [reviewed in Ref. (4, 5)]. These maturational changes are likely to play an important role in preterm infants' increased vulnerability to infections. Indeed, cytokine responses (TNF- $\alpha$, IL-6, IL- $1 \beta$, and IFN- $\gamma$ ) are decreased and skewed toward an anti-inflammatory phenotype early in gestation (5). Reduced cytokine responses have been linked to reduced downstream signaling, in part due to decreased expression of the main MyD88 signaling molecule, as well as a gestational age-dependent reduction in phosphorylation of p38 and ERK1/2 (65, 77-81). The $S$-type lectin receptor Galectin-3 is expressed on neutrophils, monocytes, macrophages, endothelial cells, and epithelial cells, can be secreted, and confers protection in Candida infection leaving galectin-3-deficient mice more susceptible to Candida infection $(82,83)$. However, conflicting results have been published regarding whether Galectin-3 levels are higher (84) or lower (83) in cord vs. adult blood and whether the levels increase (85), decrease (86), or remain constant (83) with decreasing prematurity.

\section{Dectin-1 Receptor}

Dectin-1 is a CLR and main extracellular PRR mediating the recognition of $\beta$-glucan in the Candida cell wall. Reduced Dectin-1 receptor function naturally occurs in $\sim 1 \%$ of the general population due to a genetic polymorphism that introduces a stop-codon in the CLEC7A gene encoding this receptor. Humans with this polymorphism may display a marginally increased susceptibility to cutaneous fungal infections (87). However, these infections are generally mild due to a high degree of functional redundancy with other PRRs such as Dectin-2 $(88,89)$. Upon recognition of $\beta$-glucan at the surface of Candida, a phagocytic synapse containing Dectin-1, active Src, and Syk kinases is formed (90). The intracellular signaling molecule Syk becomes phosphorylated, resulting in the cytosolic colocalization of the signalosome complex composed of CARD9, MALT1, and Bcl-10 (see Figure 1). Assembly of this protein complex leads to two main sequences of events: (1) nuclear translocation of the transcription factor and main inflammatory regulator NF- $\mathrm{kB}$, which then leads to induction of pro-inflammatory cytokine gene transcription (91) and (2) activation of the caspase- 8 enzyme, which cleaves proIL- $1 \beta$ into its mature, secreted IL- $1 \beta$ form. Because of the central importance of the signalosome complex in antifungal immune defenses, a deficiency in CARD9 or MALT1 results in a marked increased risk for invasive fungal infections in humans $(8,92$, 93). The function of Dectin-1 signaling has not been studied in premature newborns, requiring further studies to understand how this pathway may increase their susceptibility to fungal infections.

\section{ADAPTIVE IMMUNE RESPONSES}

Adaptive immune responses, mediated through dendritic cells, $\mathrm{B}$ and $\mathrm{T}$ lymphocytes, are essential to limit a Candida invasion. Following penetration of C. albicans through epithelial surfaces, dendritic cells become activated through PRR, resulting in their uptake and presentation of antigen fragments to CD4 T lymphocytes (also called "helper lymphocytes"). CD4 T cells producing the cytokine interleukin-17 (termed Th17 cells) are particularly important for controlling the proliferation of Candida, as evidenced by increased chronic mucocutaneous candidiasis in humans with genetic mutations in cytokines (e.g., IL-17A, IL-17F), receptors (e.g., IL-12 $\beta 1 R$ ), or transcription factors (e.g., RORC, GATA2, STAT1, APS-1, and ACT1) along these pathways (94). In newborns, T cells are largely naïve and display reduced activity against microbial antigens as they have not been exposed during gestation (95). Moreover, neonatal CD4 T cells are intrinsically less able to differentiate into Th17 cells due to reduced expression of the transcription factor RORC (96). Adults with genetic mutations impairing RORC or STAT3 function have increased susceptibility to chronic mucocutaneous candidiasis due to diminished Th17 function $(97,98)$. STAT3 phosphorylation occurs in neonatal $\mathrm{T}$ cells although whether reduced expression may limit Th17 differentiation in this age group is unclear (99). Neonatal T lymphocytes also have a reduced ability to differentiate into interferon- $\boldsymbol{\gamma}$-producing CD4 lymphocytes (5), which play a role protecting against fungi, through the activation of other cellular immune components (e.g., phagocytes) (9).

The role of innate immune cells in promoting the development of Th17 responses has been studied in newborns. In term newborns, antigen-presenting cells produce high levels of Th17polarizing cytokines (i.e., IL-1 $\beta$ and IL-23) (100). However, the production of these cytokines and antigen presentation are profoundly reduced in dendritic cells and monocytes of preterm infants below 29 weeks of gestation $(7,101)$, which may further contribute to their susceptibility for invasive fungal infections. Other T lymphocyte subsets such as $\gamma \delta \mathrm{T}$ cells develop early during fetal life and are able to produce interleukin-17, naturally, in an innate-like manner in the absence of effector differentiation (102). In mice, these cells are an important source of interleukin-17 (103). However, their functional role in preventing fungal invasions in premature newborns remains to be determined.

\section{LIMITATIONS OF IN VITRO STUDIES}

An important limitation of studies investigating fungal immune responses by human primary immune cells in vitro is that this situation may not reflect the complex life cycle of this microorganism during an infection in vivo. For example, heat-killed C. albicans, which is commonly used as a model in in vitro assays, exposes more $\beta$-glucan on its surface than live yeast (104). Dectin-1 specifically recognizes $\beta$-glucan structures in the cell wall of yeast, but not hyphae forms of $C$. albicans, where the $\beta$-glucan is less accessible to immune cells. As such, filamentous growth of $C$. albicans is not recognizable by Dectin-1, resulting in deficiency of ROS production and a reduction in Th17 differentiation of T cells $(104,105)$. However, Candida hyphae, but not yeast, induce a strong immune response in macrophages (71). Hyphae can specifically activate the NLRP3 inflammasome, which is important for production of IL-1 $\beta$ (106). Moreover, these changes can be strain specific (107). These limitations may significantly restrain interpretation of data. 
Likewise, experimental conditions influence the interaction between immune cells and Candida. Sasse and colleagues showed that neutrophils can phagocytose yeast Candida in a suspension (3D-setting) but fail to phagocytose opaque cells on a surface, 2D-setting (i.e., glass slide) (108). Moreover, it has been suggested that yeast are important for colonization and hyphae are responsible for invasion and that the switching between the two forms itself is responsible for activation of the immune system [reviewed in Ref. $(109,110)]$. Unfortunately, this is not accounted for in most in vitro studies as live fungal pathogens are rarely used. To mitigate these problems, animal models have been developed (111) [reviewed in Ref. (112)]. However, it is important to remember that mice are not a natural host for Candida and that considerable differences in immune functions across species warrant validation in humans (113).

\section{ENHANCING NEONATAL ANTIFUNGAL IMMUNE DEFENSES}

Basic science research findings need to be translated into clinical practice. Systemic antifungal drugs reduce the incidence of colonization and invasive fungal infections (114). However, the applicability of these approaches is somewhat limited by concerns of increasing antimicrobial resistance (115). Also, the microbial flora of preterm infants differs considerably from adults, or term infants, suggesting a role for a bacterial dysbiosis in promoting Candidemia in preterm neonates (116). Indeed, one study showed high fungal diversity in stool samples from very low-birth weight infants (117). In light of these findings, altering the gastrointestinal flora of preterm infants through the use of probiotics may represent a more viable approach to reduce the risk of invasive infections in the neonatal intensive care unit (118). Reciprocally, a better understanding of the immune response to Candida in newborns could help design vaccine interventions (119).

More research is required to understand howimmune responses can be modulated specifically in the very preterm infant. Innate

\section{REFERENCES}

1. Köhler JR, Casadevall A, Perfect J. The spectrum of fungi that infects humans. Cold Spring Harb Perspect Med (2014) 5(1):1-22. doi:10.1101/cshperspect. a019273

2. Fridkin SK, Kaufman D, Edwards JR, Shetty S, Horan T. Changing incidence of Candida bloodstream infections among NICU patients in the United States: 1995-2004. Pediatrics (2006) 117(5):1680-7. doi:10.1542/ peds.2005-1996

3. Aliaga S, Clark RH, Laughon M, Walsh TJ, Hope WW, Benjamin DK, et al. Changes in the incidence of candidiasis in neonatal intensive care units. Pediatrics (2014) 133(2):236-42. doi:10.1542/peds.20130671

4. Sharma AA, Jen R, Butler A, Lavoie PM. The developing human preterm neonatal immune system: a case for more research in this area. Clin Immunol (2012) 145(1):61-8. doi:10.1016/j.clim.2012.08.006

5. Kan B, Razzaghian HR, Lavoie PM. An immunological perspective on neonatal sepsis. Trends Mol Med (2016) 22(4):290-302. doi:10.1016/j. molmed.2016.02.001

6. Perdu S, Castellana B, Kim Y, Chan K, DeLuca L, Beristain AG. Maternal obesity drives functional alterations in uterine NK cells. JCI Insight (2016) 1(11):e85560. doi:10.1172/jci.insight. 85560 immune training using ultra-low exposure to $\beta$-glucan enhances responses to Candida in vitro (120). In support of the application of this concept to newborns, TLR and Dectin-1 co-stimulation induced strong Th1-polarizing conditions in neonatal dendritic cells in vitro (121). However, without a clear knowledge of whether these pathways are functional in premature neonates, the applicability of this strategy in preventing systemic infection in the youngest age group of neonates remains speculative. Research in this area has been traditionally hard to pursue due to obvious ethical and logistical factors $(4,122)$. Indeed, blood volumes are extremely limited in these small infants even using non-invasive sources such as the placenta. The challenge of enrolling a large enough number of premature neonates into clinical trials is also a major limitation (3). In the absence of interventional studies, basic science research remains crucial to lay the foundation for more evidence-based medicine in our approach to neonatal fungal infections.

\section{AUTHOR CONTRIBUTIONS}

$\mathrm{CM}, \mathrm{BK}$, and PL conceived, wrote, and edited this manuscript.

\section{ACKNOWLEDGMENTS}

The authors would like to thank Elizabeth A. Marchant for help in revising this manuscript.

\section{FUNDING}

Some of the research cited in this article was in part funded by the Canadian Institutes of Health Research (operating grants MOP110938; MOP-123478), the Hospital for Sick Kids Foundation, and the US March of Dimes for Birth Defects. PL is supported by a Career Investigator Award from the Michael Smith Foundation for Health Research and the BC Children's Hospital Research Institute Investigator Grant Award Program.

7. Sharma AA, Jen R, Kan B, Sharma AA, Marchant E, Tang A, et al. Impaired NLRP3 inflammasome activity during fetal development regulates IL-1 $\beta$ production in human monocytes. Eur J Immunol (2015) 45(1):238-49. doi:10.1002/eji.201444707

8. Wang X, van de Veerdonk FL, Netea MG. Basic genetics and immunology of Candida infections. Infect Dis Clin North Am (2016) 30(1):85-102. doi:10.1016/j.idc.2015.10.010

9. Richardson JP, Moyes DL. Adaptive immune responses to Candida albicans infection. Virulence (2015) 6(4):327-37. doi:10.1080/21505594. 2015.1004977

10. Manzoni P, Mostert M, Castagnola E. Update on the management of Candida infections in preterm neonates. Arch Dis Child Fetal Neonatal Ed (2015) 100(5):F454-9. doi:10.1136/archdischild-2012-303350

11. Kelly MS, Benjamin DK, Smith PB. The epidemiology and diagnosis of invasive candidiasis among premature infants. Clin Perinatol (2015) 42(1):105-17. doi:10.1016/j.clp.2014.10.008

12. Obladen M. Thrush - nightmare of the foundling hospitals. Neonatology (2012) 101(3):159-65. doi:10.1159/000329879

13. Manzoni P, Farina D, Leonessa M, d'Oulx EA, Galletto P, Mostert M, et al. Risk factors for progression to invasive fungal infection in preterm neonates with fungal colonization. Pediatrics (2006) 118(6):2359-64. doi:10.1542/ peds.2006-1311 
14. Benjamin DK, Stoll BJ, Fanaroff AA, McDonald SA, Oh W, Higgins RD, et al. Neonatal candidiasis among extremely low birth weight infants: risk factors, mortality rates, and neurodevelopmental outcomes at 18 to 22 months. Pediatrics (2006) 117(1):84-92. doi:10.1542/peds.2004-2292

15. Chryssanthou E, Broberger U, Petrini B. Malassezia pachydermatis fungaemia in a neonatal intensive care unit. Acta Paediatr (2001) 90(3):323-7. doi:10.1080/080352501300067712

16. Rogdo B, Kahlert C, Diener PA, Micallef J. Primary cutaneous aspergillosis in a preterm neonate. BMJ Case Rep (2014) 35(6):704-6. doi:10.1136/ bcr-2014-204752

17. Roilides E, Zaoutis TE, Walsh TJ. Invasive zygomycosis in neonates and children. Clin Microbiol Infect (2009) 15(Suppl 5):50-4. doi:10.1111/j.1469-0691.2009.02981.x

18. Mendiratta DK, Rawat V, Thamke D, Chaturvedi P, Chhabra S, Narang P. Candida colonization in preterm babies admitted to neonatal intensive care unit in the rural setting. Indian J Med Microbiol (2006) 24(4):263-7. doi:10.4103/0255-0857.29384

19. Pinhat EC, Borba MG, Ferreira ML, Ferreira MA, Fernandes RK, Nicolaou SK, et al. Fungal colonization in newborn babies of very low birth weight: a cohort study. J Pediatr (Rio J) (2012) 88(3):211-6. doi:10.2223/JPED.2192

20. Leibovitz E, Livshiz-Riven I, Borer A, Taraboulos-Klein T, Zamir O, Shany E, et al. A prospective study of the patterns and dynamics of colonization with Candida spp. in very low birth weight neonates. Scand J Infect Dis (2013) 45(11):842-8. doi:10.3109/00365548.2013.814150

21. Filippidi A, Galanakis E, Maraki S, Galani I, Drogari-Apiranthitou M, Kalmanti M, et al. The effect of maternal flora on Candida colonisation in the neonate. Mycoses (2014) 57(1):43-8. doi:10.1111/myc.12100

22. Lupetti A, Tavanti A, Davini P, Ghelardi E, Corsini V, Merusi I, et al. Horizontal transmission of Candida parapsilosis candidemia in a neonatal intensive care unit. J Clin Microbiol (2002) 40(7):2363-9. doi:10.1128/ JCM.40.7.2363-2369.2002

23. Bliss JM, Basavegowda KP, Watson WJ, Sheikh AU, Ryan RM. Vertical and horizontal transmission of Candida albicans in very low birth weight infants using DNA fingerprinting techniques. Pediatr Infect Dis J (2008) 27(3):231-5. doi:10.1097/INF.0b013e31815bb69d

24. Hernández-Castro R, Arroyo-Escalante S, Carrillo-Casas EM, MoncadaBarrón D, Álvarez-Verona E, Hernández-Delgado L, et al. Outbreak of Candida parapsilosis in a neonatal intensive care unit: a health care workers source. Eur J Pediatr (2010) 169(7):783-7. doi:10.1007/s00431-009-1109-7

25. Lackner A, Stammberger H, Buzina W, Freudenschuss K, Panzitt T, Schosteritsch S, et al. Fungi: a normal content of human nasal mucus. Am J Rhinol (2005) 19(2):125-9.

26. Stecksén-Blicks C, Granström E, Silfverdal SA, West CE. Prevalence of oral Candida in the first year of life. Mycoses (2015) 58(9):550-6. doi:10.1111/ myc. 12355

27. Hannula J, Saarela M, Jousimies-Somer H, Takala A, Syrjänen R, Könönen E, et al. Age-related acquisition of oral and nasopharyngeal yeast species and stability of colonization in young children. Oral Microbiol Immunol (1999) 14(3):176-82. doi:10.1034/j.1399-302X.1999.140306.x

28. Huffnagle GB, Noverr MC. The emerging world of the fungal microbiome. Trends Microbiol (2013) 21(7):334-41. doi:10.1016/j.tim.2013.04.002

29. Manzoni P, Mostert M, Jacqz-Aigrain E, Stronati M, Farina D. Candida colonization in the nursery. J Pediatr (Rio J) (2012) 88(3):187-90. doi:10.2223/ JPED.2201

30. Kaufman DA, Gurka MJ, Hazen KC, Boyle R, Robinson M, Grossman LB. Patterns of fungal colonization in preterm infants weighing less than 1000 grams at birth. Pediatr Infect Dis J (2006) 25(8):733-7. doi:10.1097/01. inf.0000226978.96218.e6

31. Oeser C, Vergnano S, Naidoo R, Anthony M, Chang J, Chow P, et al. Neonatal invasive fungal infection in England 2004-2010. Clin Microbiol Infect (2014) 20(9):936-41. doi:10.1111/1469-0691.12578

32. Pemán J, Cantón E, Linares-Sicilia MJ, Roselló EM, Borrell N, Ruiz-Pérez-dePipaon MT, et al. Epidemiology and antifungal susceptibility of bloodstream fungal isolates in pediatric patients: a Spanish multicenter prospective survey. J Clin Microbiol (2011) 49(12):4158-63. doi:10.1128/JCM.05474-11

33. Pammi M, Holland L, Butler G, Gacser A, Bliss JM. Candida parapsilosis is a significant neonatal pathogen: a systematic review and meta-analysis. Pediatr Infect Dis J (2013) 32(5):e206-16. doi:10.1097/INF.0b013e3182863alc
34. Palazzi DL, Arrieta A, Castagnola E, Halasa N, Hubbard S, Brozovich AA, et al. Candida speciation, antifungal treatment and adverse events in pediatric invasive candidiasis. Pediatr Infect Dis J (2014) 33(12):1294-6. doi:10.1097/ INF.0000000000000431

35. Cotten CM, McDonald S, Stoll B, Goldberg RN, Poole K, Benjamin DK, et al. The association of third-generation cephalosporin use and invasive candidiasis in extremely low birth-weight infants. Pediatrics (2006) 118(2):717-22. doi:10.1542/peds.2005-2677

36. Stoll BJ, Hansen N, Fanaroff AA, Wright LL, Carlo WA, Ehrenkranz RA, et al. Late-onset sepsis in very low birth weight neonates: the experience of the NICHD Neonatal Research Network. Pediatrics (2002) 110(2 Pt 1):285-91. doi:10.1542/peds.110.2.285

37. Barton M, O’Brien K, Robinson JL, Davies DH, Simpson K, Asztalos $\mathrm{E}$, et al. Invasive candidiasis in low birth weight preterm infants: risk factors, clinical course and outcome in a prospective multicenter study of cases and their matched controls. BMC Infect Dis (2014) 14:327. doi:10.1186/1471-2334-14-327

38. Chen J, Yu X, Zhou Y, Zhang Y, Zhu J, Xie L, et al. Integrated measures for prevention of invasive Candida infections in preterm infants in a Chinese neonatal intensive care unit. Am J Infect Control (2015) 43(12):1321-5. doi:10.1016/j.ajic.2015.07.011

39. Wächtler B, Citiulo F, Jablonowski N, Förster S, Dalle F, Schaller M, et al. Candida albicans-epithelial interactions: dissecting the roles of active penetration, induced endocytosis and host factors on the infection process. PLoS One (2012) 7(5):e36952. doi:10.1371/journal.pone.0036952

40. Cohen-Kedar S, Baram L, Elad H, Brazowski E, Guzner-Gur H, Dotan I. Human intestinal epithelial cells respond to $\beta$-glucans via dectin- 1 and Syk. Eur J Immunol (2014) 44(12):3729-40. doi:10.1002/eji.201444876

41. Tollin M, Bergsson G, Kai-Larsen Y, Lengqvist J, Sjövall J, Griffiths W, et al. Vernix caseosa as a multi-component defence system based on polypeptides, lipids and their interactions. Cell Mol Life Sci (2005) 62(19-20):2390-9. doi:10.1007/s00018-005-5260-7

42. Pickens WL, Warner RR, Boissy YL, Boissy RE, Hoath SB. Characterization of vernix caseosa: water content, morphology, and elemental analysis. J Invest Dermatol (2000) 115(5):875-81. doi:10.1046/j.1523-1747.2000.00134.x

43. Battersby AJ, Khara J, Wright VJ, Levy O, Kampmann B. Antimicrobial proteins and peptides in early life: ontogeny and translational opportunities. Front Immunol (2016) 7:309. doi:10.3389/fimmu.2016.00309

44. Vento G, Lio A, Tirone C, Aurilia C, Tana M, Piras A, et al. Association of high levels of $\alpha$-defensins and S100A proteins with Candida mannan detection in bronchoalveolar lavage fluid of preterm neonates. Pediatr Res (2013) 74(1):19-25. doi:10.1038/pr.2013.60

45. Tsoni SV, Kerrigan AM, Marakalala MJ, Srinivasan N, Duffield M, Taylor PR, et al. Complement C3 plays an essential role in the control of opportunistic fungal infections. Infect Immun (2009) 77(9):3679-85. doi:10.1128/ IAI.00233-09

46. Cheng SC, Sprong T, Joosten LAB, van der Meer JWM, Kullberg BJ, Hube B, et al. Complement plays a central role in Candida albicans-induced cytokine production by human PBMCs. Eur J Immunol (2012) 42(4):993-1004. doi:10.1002/eji.201142057

47. Osofsky SG, Thompson BH, Lint TF, Gewurz H. Hereditary deficiency of the third component of complement in a child with fever, skin rash, and arthralgias: response to transfusion of whole blood. J Pediatr (1977) 90(2):180-6. doi:10.1016/S0022-3476(77)80626-4

48. Naked GM, Florido MP, Ferreira de Paula P, Vinet AM, Inostroza JS, Isaac L. Deficiency of human complement factor I associated with lowered factor $\mathrm{H}$. Clin Immunol (2000) 96(2):162-7. doi:10.1006/clim.2000.4878

49. Drew JH, Arroyave CM. The complement system of the newborn infant. Biol Neonate (1980) 37(3-4):209-17. doi:10.1159/000241276

50. Grumach AS, Ceccon ME, Rutz R, Fertig A, Kirschfink M. Complement profile in neonates of different gestational ages. Scand J Immunol (2014) 79(4):276-81. doi:10.1111/sji.12154

51. Wolach B, Dolfin T, Regev R, Gilboa S, Schlesinger M. The development of the complement system after 28 weeks' gestation. Acta Paediatr (1997) 86(5):523-7. doi:10.1111/j.1651-2227.1997.tb08924.x

52. Netea MG, Joosten LAB, van der Meer JWM, Kullberg B-J, van de Veerdonk FL. Immune defence against Candida fungal infections. Nat Rev Immunol (2015) 15(10):630-42. doi:10.1038/nri3897 
53. Basu S, Quilici C, Zhang H-H, Grail D, Dunn AR. Mice lacking both G-CSF and IL-6 are more susceptible to Candida albicans infection: critical role of neutrophils in defense against Candida albicans. Growth Factors (2008) 26(1):23-34. doi:10.1080/08977190801987513

54. Koh AY, Köhler JR, Coggshall KT, Van Rooijen N, Pier GB. Mucosal damage and neutropenia are required for Candida albicans dissemination. PLoS Pathog (2008) 4(2):e35. doi:10.1371/journal.ppat.0040035

55. Gazendam RP, van de Geer A, Roos D, van den Berg TK, Kuijpers TW. How neutrophils kill fungi. Immunol Rev (2016) 273(1):299-311. doi:10.1111/ imr. 12454

56. Menegazzi R, Decleva E, Dri P. Killing by neutrophil extracellular traps: fact or folklore? Blood (2012) 119(5):1214-6. doi:10.1182/blood-2011-07-364604

57. Urban CF, Ermert D, Schmid M, Abu-Abed U, Goosmann C, Nacken W, et al. Neutrophil extracellular traps contain calprotectin, a cytosolic protein complex involved in host defense against Candida albicans. PLoS Pathog (2009) 5(10):e1000639. doi:10.1371/journal.ppat.1000639

58. Byrd AS, O’Brien XM, Laforce-Nesbitt SS, Parisi VE, Hirakawa MP, Bliss JM, et al. NETosis in neonates: evidence of a reactive oxygen species-independent pathway in response to fungal challenge. J Infect Dis (2016) 213(4):634-9. doi:10.1093/infdis/jiv435

59. Horn DL, Neofytos D, Anaissie EJ, Fishman JA, Steinbach WJ, Olyaei AJ, et al. Epidemiology and outcomes of candidemia in 2019 patients: data from the prospective antifungal therapy alliance registry. Clin Infect Dis (2009) 48(12):1695-703. doi:10.1086/599039

60. Mouzinho A, Rosenfeld CR, Sanchez PJ, Risser R. Revised reference ranges for circulating neutrophils in very-low-birth-weight neonates. Pediatrics (1994) 94(1):76-82.

61. Lavoie PM, Levy O. Mononuclear phagocyte system. Fetal and Neonatal Physiology. Elsevier (2017). p. 1208-16.e3. doi:10.1016/B978-0-323-352147.00125-6

62. Sarkar S, Bhagat I, Hieber S, Donn SM. Can neutrophil responses in very low birth weight infants predict the organisms responsible for late-onset bacterial or fungal sepsis? J Perinatol (2006) 26(8):501-5. doi:10.1038/sj.jp.7211554

63. Al-Hadithy H, Addison IE, Goldstone AH, Cawley JC, Shaw JC. Defective neutrophil function in low-birth-weight, premature infants. J Clin Pathol (1981) 34(4):366-70. doi:10.1136/jcp.34.4.366

64. Destin KG, Linden JR, Laforce-Nesbitt SS, Bliss JM. Oxidative burst and phagocytosis of neonatal neutrophils confronting Candida albicans and Candida parapsilosis. Early Hum Dev (2009) 85(8):531-5. doi:10.1016/j. earlhumdev.2009.05.011

65. Currie AJ, Curtis S, Strunk T, Riley K, Liyanage K, Prescott S, et al. Preterm infants have deficient monocyte and lymphocyte cytokine responses to group B Streptococcus. Infect Immun (2011) 79(4):1588-96. doi:10.1128/ IAI.00535-10

66. Prosser A, Hibbert J, Strunk T, Kok CH, Simmer K, Richmond P, et al. Phagocytosis of neonatal pathogens by peripheral blood neutrophils and monocytes from newborn preterm and term infants. Pediatr Res (2013) 74(5):503-10. doi:10.1038/pr.2013.145

67. Xanthou M, Valassi-Adam E, Kintsonidou E, Matsaniotis N. Phagocytosis and killing ability of Candida albicans by blood leucocytes of healthy term and preterm babies. Arch Dis Child (1975) 50(1):72-5. doi:10.1136/adc.50.1.72

68. McDonald JU, Rosas M, Brown GD, Jones SA, Taylor PR. Differential dependencies of monocytes and neutrophils on dectin-1, dectin-2 and complement for the recognition of fungal particles in inflammation. PLoS One (2012) 7(9):e45781. doi:10.1371/journal.pone.0045781

69. Chaffin WL, López-Ribot JL, Casanova M, Gozalbo D, Martínez JP. Cell wall and secreted proteins of Candida albicans: identification, function, and expression. Microbiol Mol Biol Rev (1998) 62(1):130-80.

70. Gow NAR, van de Veerdonk FL, Brown AJP, Netea MG. Candida albicans morphogenesis and host defence: discriminating invasion from colonization. Nat Rev Microbiol (2011) 10(2):112-22. doi:10.1038/nrmicro2711

71. Lowman DW, Greene RR, Bearden DW, Kruppa MD, Pottier M, Monteiro MA, et al. Novel structural features in Candida albicans hyphal glucan provide a basis for differential innate immune recognition of hyphae versus yeast. J Biol Chem (2014) 289(6):3432-43. doi:10.1074/jbc.M113.529131

72. Ifrim DC, Joosten LAB, Kullberg B-J, Jacobs L, Jansen T, Williams DL, et al. Candida albicans primes TLR cytokine responses through a dectin-1/
Raf-1-mediated pathway. J Immunol (2013) 190(8):4129-35. doi:10.4049/ jimmunol.1202611

73. Netea MG, Van Der Graaf CAA, Vonk AG, Verschueren I, Van Der Meer JWM, Kullberg BJ. The role of toll-like receptor (TLR) 2 and TLR4 in the host defense against disseminated candidiasis. J Infect Dis (2002) 185(10):1483-9. doi:10.1086/340511

74. Bourgeois C, Kuchler K. Fungal pathogens-a sweet and sour treat for toll-like receptors. Front Cell Infect Microbiol (2012) 2:142. doi:10.3389/ fcimb.2012.00142

75. Sharma AA, Jen R, Brant R, Ladd M, Huang Q, Skoll A, et al. Hierarchical maturation of innate immune defences in very preterm neonates. Neonatology (2014) 106(1):1-9. doi:10.1159/000358550

76. Marr N, Wang T-I, Kam SHY, Hu YS, Sharma AA, Lam A, et al. Attenuation of respiratory syncytial virus-induced and RIG-I-dependent type I IFN responses in human neonates and very young children. J Immunol (2014) 192(3):948-57. doi:10.4049/jimmunol.1302007

77. Sadeghi K, Berger A, Langgartner M, Prusa A-RA, Hayde M, Herkner K, et al. Immaturity of infection control in preterm and term newborns is associated with impaired toll-like receptor signaling. J Infect Dis (2007) 195(2):296-302. doi:10.1086/509892

78. Strunk T, Prosser A, Levy O, Philbin V, Simmer K, Doherty D, et al. Responsiveness of human monocytes to the commensal bacterium Staphylococcus epidermidis develops late in gestation. Pediatr Res (2012) 72(1):10-8. doi:10.1038/pr.2012.48

79. Strunk T, Temming P, Gembruch U, Reiss I, Bucsky P, Schultz C. Differential maturation of the innate immune response in human fetuses. Pediatr Res (2004) 56(2):219-26. doi:10.1203/01. PDR.0000132664.66975.79

80. Marchant EA, Kan B, Sharma AA, van Zanten A, Kollmann TR, Brant R, et al. Attenuated innate immune defenses in very premature neonates during the neonatal period. Pediatr Res (2015) 78(5):492-7. doi:10.1038/pr.2015.132

81. Belderbos ME, van Bleek GM, Levy O, Blanken MO, Houben ML, Schuijff $\mathrm{L}$, et al. Skewed pattern of toll-like receptor 4-mediated cytokine production in human neonatal blood: low LPS-induced IL-12p70 and high IL-10 persist throughout the first month of life. Clin Immunol (2009) 133(2):228-37. doi:10.1016/j.clim.2009.07.003

82. Esteban A, Popp MW, Vyas VK, Strijbis K, Ploegh HL, Fink GR. Fungal recognition is mediated by the association of dectin-1 and galectin-3 in macrophages. Proc Natl Acad Sci U S A (2011) 108(34):14270-5. doi:10.1073/ pnas. 1111415108

83. Linden JR, De Paepe ME, Laforce-Nesbitt SS, Bliss JM. Galectin-3 plays an important role in protection against disseminated candidiasis. Med Mycol (2013) 51(6):641-51. doi:10.3109/13693786.2013.770607

84. Sundqvist M, Osla V, Jacobsson B, Rudin A, Sävman K, Karlsson A. Cord blood neutrophils display a galectin-3 responsive phenotype accentuated by vaginal delivery. BMC Pediatr (2013) 13:128. doi:10.1186/1471-2431-13-128

85. Demmert M, Faust K, Bohlmann MK, Tröger B, Göpel W, Herting E, et al. Galectin-3 in cord blood of term and preterm infants. Clin Exp Immunol (2012) 167(2):246-51. doi:10.1111/j.1365-2249.2011.04509.x

86. Chan C, Bode L, Kim J. Galectin-3 binding protein in human preterm infant umbilical cord plasma. J Neonatal Perinatal Med (2015) 8(2):99-104. doi:10.3233/NPM-15814055

87. Rosentul DC, Plantinga TS, Oosting M, Scott WK, Velez Edwards DR, Smith $\mathrm{PB}$, et al. Genetic variation in the dectin-1/CARD9 recognition pathway and susceptibility to candidemia. J Infect Dis (2011) 204(7):1138-45. doi:10.1093/ infdis/jir458

88. Gringhuis SI, Wevers BA, Kaptein TM, van Capel TMM, Theelen B, Boekhout $\mathrm{T}$, et al. Selective C-Rel activation via Malt1 controls anti-fungal T(H)-17 immunity by dectin-1 and dectin-2. PLoS Pathog (2011) 7(1):e1001259. doi:10.1371/journal.ppat.1001259

89. Ferwerda B, Ferwerda G, Plantinga TS, Willment JA, van Spriel AB, Venselaar $\mathrm{H}$, et al. Human dectin-1 deficiency and mucocutaneous fungal infections. $N$ Engl J Med (2009) 361(18):1760-7. doi:10.1056/NEJMoa0901053

90. Goodridge HS, Reyes CN, Becker CA, Katsumoto TR, Ma J, Wolf AJ, et al. Activation of the innate immune receptor dectin-1 upon formation of a "phagocytic synapse". Nature (2011) 472(7344):471-5. doi:10.1038/ nature10071 
91. Gross O, Gewies A, Finger K, Schäfer M, Sparwasser T, Peschel C, et al. Card9 controls a non-TLR signalling pathway for innate anti-fungal immunity. Nature (2006) 442(7103):651-6. doi:10.1038/nature04926

92. Glocker E-O, Hennigs A, Nabavi M, Schäffer AA, Woellner C, Salzer U, et al. A homozygous CARD9 mutation in a family with susceptibility to fungal infections. N Engl JMed (2009) 361(18):1727-35. doi:10.1056/ NEJMoa0810719

93. Turvey SE, Durandy A, Fischer A, Fung S-Y, Geha RS, Gewies A, et al. The CARD11-BCL10-MALT1 (CBM) signalosome complex: stepping into the limelight of human primary immunodeficiency. J Allergy Clin Immunol (2014) 134(2):276-84. doi:10.1016/j.jaci.2014.06.015

94. Cypowyj S, Picard C, Maródi L, Casanova J-L, Puel A. Immunity to infection in IL-17-deficient mice and humans. Eur J Immunol (2012) 42(9):2246-54. doi:10.1002/eji.201242605

95. Dowling DJ, Levy O. Ontogeny of early life immunity. Trends Immunol (2014) 35(7):299-310. doi:10.1016/j.it.2014.04.007

96. De Roock S, Stoppelenburg AJ, Scholman R, Hoeks SB, Meerding J, Prakken BJ, et al. Defective TH17 development in human neonatal T cells involves reduced RORC2 mRNA content. J Allergy Clin Immunol (2013) 132(3):1-6. doi:10.1016/j.jaci.2013.04.014

97. Ma CS, Chew GYJ, Simpson N, Priyadarshi A, Wong M, Grimbacher B, et al. Deficiency of Th17 cells in hyper IgE syndrome due to mutations in STAT3. J Exp Med (2008) 205(7):1551-7. doi:10.1084/jem.20080218

98. Okada S, Markle JG, Deenick EK, Mele F, Averbuch D, Lagos M, et al. IMMUNODEFICIENCIES. Impairment of immunity to Candida and Mycobacterium in humans with bi-allelic RORC mutations. Science (2015) 349(6248):606-13. doi:10.1126/science.aaa4282

99. Caron JE, La Pine TR, Augustine NH, Martins TB, Kumánovics A, Hill HR. Severely depressed interleukin-17 production by human neonatal mononuclear cells. Pediatr Res (2014) 76(6):2-7. doi:10.1038/pr.2014.133

100. Vanden Eijnden S, Goriely S, De Wit D, Goldman M, Willems F. Preferential production of the IL-12(40)/IL-23(p19) heterodimer by dendritic cells from human newborns. Eur J Immunol (2006) 36(1):21-6. doi:10.1002/ eji.200535467

101. Lavoie PMM, Huang Q, Jolette E, Whalen M, Nuyt AMM, Audibert F, et al. Profound lack of interleukin (IL)-12/IL-23p40 in neonates born early in gestation is associated with an increased risk of sepsis. J Infect Dis (2010) 202(11):1754-63. doi:10.1086/657143

102. Haas JDD, Ravens S, Düber S, Sandrock I, Oberdörfer L, Kashani E, et al. Development of interleukin-17-producing $\gamma \mathrm{d} \mathrm{T}$ cells is restricted to a functional embryonic wave. Immunity (2012) 37(1):48-59. doi:10.1016/j. immuni.2012.06.003

103. Conti HR, Peterson AC, Brane L, Huppler AR, Hernández-Santos N, Whibley $\mathrm{N}$, et al. Oral-resident natural Th17 cells and $\gamma \mathrm{d}$ T cells control opportunistic Candida albicans infections. J Exp Med (2014) 211(10):2075-84. doi:10.1084/ jem.20130877

104. Gantner BN, Simmons RM, Underhill DM. Dectin-1 mediates macrophage recognition of Candida albicans yeast but not filaments. EMBO J (2005) 24(6):1277-86. doi:10.1038/sj.emboj.7600594

105. Kashem SW, Igyártó BZ, Gerami-Nejad M, Kumamoto Y, Mohammed J, Jarrett E, et al. Candida albicans morphology and dendritic cell subsets determine $\mathrm{T}$ helper cell differentiation. Immunity (2015) 42(2):356-66. doi:10.1016/j.immuni.2015.01.008

106. Joly S, Ma N, Sadler JJ, Soll DR, Cassel SL, Sutterwala FS. Cutting edge: Candida albicans hyphae formation triggers activation of the Nlrp3 inflammasome. J Immunol (2009) 183(6):3578-81. doi:10.4049/ jimmunol.0901323

107. Marakalala MJ, Vautier S, Potrykus J, Walker LA, Shepardson KM, Hopke A, et al. Differential adaptation of Candida albicans in vivo modulates immune recognition by dectin-1. PLoS Pathog (2013) 9(4):e1003315. doi:10.1371/ journal.ppat.1003315

108. Sasse C, Hasenberg M, Weyler M, Gunzer M, Morschhäuser J. Whiteopaque switching of Candida albicans allows immune evasion in an environment-dependent fashion. Eukaryot Cell (2013) 12(1):50-8 doi:10.1128/EC.00266-12

109. Rizzetto L, Weil T, Cavalieri D. Systems level dissection of Candida recognition by dectins: a matter of fungal morphology and site of infection. Pathogens (2015) 4(3):639-61. doi:10.3390/pathogens4030639

110. Chin VK, Lee TY, Rusliza B, Chong PP. Dissecting Candida albicans infection from the perspective of C. albicans virulence and omics approaches on host-pathogen interaction: a review. Int J Mol Sci (2016) 17(10):1643. doi:10.3390/ijms17101643

111. Tsai NY, Laforce-Nesbitt SS, Tucker R, Bliss JM. A murine model for disseminated candidiasis in neonates. Pediatr Res (2011) 69(3):189-93. doi:10.1203/ PDR.0b013e318206fd3e

112. Koh AY. Murine models of Candida gastrointestinal colonization and dissemination. Eukaryot Cell (2013) 12(11):1416-22. doi:10.1128/EC.00196-13

113. Duggan S, Leonhardt I, Hünniger K, Kurzai O. Host response to Candida albicans bloodstream infection and sepsis. Virulence (2015) 6:316-26. doi:10.4161/21505594.2014.988096

114. Cleminson J, Austin N, McGuire W. Prophylactic systemic antifungal agents to prevent mortality and morbidity in very low birth weight infants. Cochrane Database Syst Rev (2015) (10):CD003850. doi:10.1002/14651858.CD003850. pub5

115. Ostrosky-Zeichner L, Rex JH, Pappas PG, Hamill RJ, Larsen RA, Horowitz $\mathrm{HW}$, et al. Antifungal susceptibility survey of 2,000 bloodstream Candida isolates in the United States. Antimicrob Agents Chemother (2003) 47(10):3149-54. doi:10.1128/AAC.47.10.3149-3154.2003

116. Unger S, Stintzi A, Shah P, Mack D, O'Connor DL. Gut microbiota of the very low birth weight infant. Pediatr Res (2014) 77(1):205-13. doi:10.1038/ pr.2014.162

117. LaTuga MS, Ellis JC, Cotton CM, Goldberg RN, Wynn JL, Jackson RB, et al. Beyond bacteria: a study of the enteric microbial consortium in extremely low birth weight infants. PLoS One (2011) 6(12):e27858. doi:10.1371/journal. pone.0027858

118. Manzoni P, Mostert M, Leonessa ML, Priolo C, Farina D, Monetti C, et al. Oral supplementation with Lactobacillus casei subspecies rhamnosus prevents enteric colonization by Candida species in preterm neonates: a randomized study. Clin Infect Dis (2006) 42(12):1735-42. doi:10.1086/504324

119. Schmidt CS, White CJ, Ibrahim AS, Filler SG, Fu Y, Yeaman MR, et al. NDV3, a recombinant alum-adjuvanted vaccine for Candida and Staphylococcus aureus, is safe and immunogenic in healthy adults. Vaccine (2012) 30(52):7594-600. doi:10.1016/j.vaccine.2012.10.038

120. Quintin J, Saeed S, Martens JHA, Giamarellos-Bourboulis EJ, Ifrim DC, Logie C, et al. Candida albicans infection affords protection against reinfection via functional reprogramming of monocytes. Cell Host Microbe (2012) 12(2):223-32. doi:10.1016/j.chom.2012.06.006

121. Lemoine S, Jaron B, Tabka S, Ettreiki C, Deriaud E, Zhivaki D, et al. Dectin-1 activation unlocks IL12A expression and reveals the TH1 potency of neonatal dendritic cells. J Allergy Clin Immunol (2015) 136(5):.e1-15. doi:10.1016/j. jaci.2015.02.030

122. Strunk T, Currie A, Richmond P, Simmer K, Burgner D. Innate immunity in human newborn infants: prematurity means more than immaturity. J Matern Fetal Neonatal Med (2011) 24(1):25-31. doi:10.3109/14767058.2010.482605

Conflict of Interest Statement: The authors declare that the research was conducted in the absence of any commercial or financial relationships that could be construed as a potential conflict of interest.

Copyright (C) 2017 Michalski, Kan and Lavoie. This is an open-access article distributed under the terms of the Creative Commons Attribution License (CC BY). The use, distribution or reproduction in other forums is permitted, provided the original author(s) or licensor are credited and that the original publication in this journal is cited, in accordance with accepted academic practice. No use, distribution or reproduction is permitted which does not comply with these terms. 